\title{
Information and communication technologies in distance education for improving competence of students in the university
}

\section{Tecnologías de la información y la comunicación en la educación a distancia para mejorar la competencia de los estudiantes en la universidad}

\author{
Anton V. Lebedev \\ toshaleb@mail.ru \\ https://orcid.org/0000-0002-1927-5595 \\ Foreign Languages Department, National Research Ogarev Mordovia State University, \\ Saransk, Russia \\ Mariia I. Murneva \\ mashamurneva@yandex.ru \\ https://orcid.org/0000-0003-4788-1434 \\ Foreign Languages Department, National Research Ogarev Mordovia State University, \\ Saransk, Russia \\ Nadezhda A. Shestakova \\ Shestakovanady@yandex.ru \\ https://orcid.org/0000-0001-8425-4021 \\ Foreign Languages Department, National Research Ogarev Mordovia State University, \\ Saransk, Russia \\ Iuliia S. Pinkovetskaia \\ judy54@yandex.ru \\ https://orcid.org/0000-0002-8224-9031 \\ Economic Analysis and State Management Department, Ulyanovsk State University, \\ Ulyanovsk, Russia \\ Marina V. Bakanova \\ bakanova_marina@list.ru \\ https://orcid.org/0000-0002-4270-2532 \\ Translation and Translation Studies Department, Penza State University, Penza, Russia
}

Recibido: 08/05/21

Aceptado: $12 / 07 / 21$

\section{Abstract}

The objective of the study was to develop and implement modern information and communication technologies in the online learning process of university students. The 
subject of the study is the modernization of the educational process based on communicative competence in distance education. The sociological survey carried out showed the high effectiveness of the proposed methodology. The article presents the practical foundations of the application of information and communication technology in the implementation of distance education in the context of the Covid-19 pandemic. The results of the study made it possible to develop modern means of information and communication, including video and remote-controlled complexes.

Keywords: information and communication technologies, communicative competence, distance education, academic english, e-learning.

\section{Resumen}

El objetivo del estudio es desarrollar e implementar tecnologías modernas de información y comunicación en el proceso de aprendizaje en línea de los estudiantes universitarios. El tema del estudio es la modernización del proceso educativo basado en la competencia comunicativa en la educación a distancia. La encuesta sociológica realizada mostró la alta efectividad de la metodología propuesta. El artículo presenta los fundamentos prácticos de la aplicación de la tecnología de la información y las comunicaciones en la implementación de la educación a distancia en el contexto de la pandemia Covid-19. Los resultados del estudio permitieron desarrollar medios modernos de información y comunicación, incluidos los complejos de video y teledirigidos.

Palabras clave: tecnología de la información y las comunicaciones, competencia comunicativa, educación a distancia, inglés académico, e-Learning.

\section{Introduction}

The globalization and the current conditions of the Covid-19 pandemic justifies the introduction of information and communication technologies into online format as a relevant learning tool. Synthesis of the traditional forms of education with information and communication technologies is constantly increasing in importance. The learning process at National Ogarev Mordovia State University (MRSU) is no exception. The development of information and communication technologies as one of the effective forms in achieving high results in the educational process turned out to be under close scrutiny by many teaching and academic experts. This is one of the most important components of the developing system of open education within the framework of the Bologna process in Russia.

The wide use of modern trends in the development of information and communication technologies in distance learning is associated with the period of the pandemic. The transition from traditional forms of education became especially pressing at the very beginning of the pandemic. It beca me evident that teachers were not prepared for the active use of distance learning formats. Therefore, it became necessary to adequately develop and implement information and communication technologies in distance 
๔eduweb

Revista de Tecnología de Información y Comunicación en Educación • Volumen 15, № 2. Mayo-agosto 2021

education at technical faculties while teaching Academic English. There is an increased need to improve training practices, techniques and approaches to defining such a critical aspect, owing to the demand in comprehensive research in the management and perception of information and communication technologies.

Aim of the research are developing and implementation of modern information and communication technologies in the process of online learning of Academic English by students at MRSU. The subject of the research is the modernization of the educational process for the formation of communicative competence in distance education by designating modern technologies for the development of communicative technologies.

Research tasks:

- apply modern technologies and techniques for the development of communication technologies;

- format the ability to use modern information and communication technologies as a result of teaching;

- develop the professional communication and teaching skills as the main component of immersion in an academic foreign language environment;

- increase the professional and communication abilities to implement the academic goals in the context of distance education;

- implement the professionally oriented communicative self- and mutual learning as a type of joint educational activity for academic purposes;

- organize the process of mastering academic English in the context of implementing the concept of the professionally oriented approach by following the modern trends in media education.

The academic significance of the presented study is determined by an integrated approach to the analysis of the development of modern information and communication technologies and their influence on the improvement of communicative competence in leaning Academic English in the context of distance learning at the technical faculties of Ogarev Mordovia State University.

\section{Literature Review}

Different interpretations of the understanding of distance education are explained by the ambiguity and capacity of the modern educational process, and, accordingly, the versatility of the implementation of educational activities. Investigating certain aspects of digitalization of the educational process at the university, Vaks (2021) emphasizes that "distance learning is the first stage of adaptation of students to social and professional interaction in the context of the digitalization of the economy". Lebedev et al. (2020) point out that the increase of international cooperation, trade, tourism and emigration arouses the interest of both linguists and teaching experts in the theory and practice of the elearning and mobile teaching technologies. 
Some authors also deal with the issues of IT-development in the learning process. For instance, Gao and Zhang (2020) consider how English teachers were coping with the challenges, what cognitions they possess about features, advantages, and constraints of online EFL teaching, as well as how they acquired information and communication technology (ICT) literacy through understanding students' learning needs. The survey by Gleason and Manca (2020) is devoted to pedagogical approaches to teaching and learning with social media (especially Twitter) in higher education framework.

Martin (2020) studies the issues of pronunciation development and instruction in distance language learning using the innovative computer-assisted method of pronunciation learning over the one-semester course with 67 distance learners. The paper by Foung and Chen (2019) features the data to discover the pattern of use of the online learning package within a generic undergraduate academic skills course; the study analyzed usage logs for over 7000 students that could be accessed via the university's learning management system. The issue of e-learning adoption in emergency situations, specifically, the case of a Vietnamese university under COVID-19 conditions, has become a topic for study by Ho et al. (2020). The survey results, obtained from two higher schools of the Vietnamese educational system, aim to disclose the vital factors contributing to students' acceptance of e-learning during the Covid-19 high-peak period. To achieve this goal, the bilingual questionnaire in English and Vietnamese was provided and pre-tested on 30 participants.

Marcum and Kim (2020) review the topic of oral language skills in the context of e-learning of the English language by investigating the efficiency of an online distance-learning program in assisting students in their development of the oral English-language proficiency before entering a university in the United States. According to Murneva et al. (2018), it is necessary to consider the students' individual characteristics and try to make students treat the proposed tasks not as exercises, but as a speech act.

\section{Methodology}

Researchers consider distance learning forms as the integration, adaptation and optimization of the professional educational process within the framework of the traditional education system. This demands transition from the traditional system of values and accepted norms into the phase of active knowledge acquisition, based on the interactive and constructive joint activities of a student and an instructor, which can be expressed by the following strategy: traditional education - distance learning format creative approach - understanding the need for education - information and communication technologies - independence - obtaining knowledge by a student. Such a model of the student-instructor relationship implies a transition from the authoritarian aspect in the learning and teaching style, which implements the concept of an individual approach to the study of Academic English in the context of distance education at technical faculties, and is focused on the students' personal characteristics, their intellectual capabilities and individual cognitive needs. 
The transition from teaching with a textbook as a traditionally prevailing form of educational activity is carried out through the development and implementing information and communication technologies that encourage speech self-expression. In this regard, the formation of communicative competence is viewed not as routine memorization and cramming, but as a deep understanding of the need to acquire knowledge. It is actualized in the student's communicative activity in the context of distance learning through the use of electronic resources and electronic learning platforms, such as Internet databases, multimedia teaching aids, and the implementation of information and communication technologies in distance learning carried out through webinars, quizzes, online dialogues, seminars, conferences, round tables, etc.

Researchers at MRSU have developed a number of modern techniques, information and communication technologies and exercises for the development of a student's communicative competence in online learning for mastering communication skills and abilities. In the conditions of distance learning a student is required to learn to improve, self-organize and develop intellectually, devoting sufficient time and resources to developing speech and expanding both active and passive vocabulary. This involves intensive training, public speaking and speech assignments to improve the communicative aspect of distance education. The result directly depends on the correctly set goal, therefore, before organizing work on the development of methods, technologies and exercises aimed at communicative competence the student needs to clearly understand the result to be achieved.

The ability to clearly and correctly express one's thoughts in the distance learning format is not only a basic skill, but also an opportunity to feel comfortable when conducting social communication. Accordingly, command of the cutting-edge communication technologies is fundamental to the success of each individual. Individual ability to express ideas is an obligatory part of a person`s mental and physiological development, as wellas the skills to extract words and expressions from the subconscious in such a way that it would be acceptable and interesting for others to listen. This demands an acquired set of skillsthat requires additional mental efforts and methodological practices, technologies and techniques. The team of researchers have developed exercises that contribute to the development and improvement of communication skills and abilities in students, including the following:

1. the communicative competence and communication skills when learning online;

2. learning basics of speech ethics;

3. forming online speech behavior culture;

4. establishing the advanced oratory skills in learning online;

5. elimination of fear of public speaking.

In order to successfully implement modern technologies for teaching communicative competence and to form speech skills and skills for online work, it is critical to apply a number of modern communication technologies and techniques for the speech 
development. This implies the integrated approach, which includes techniques and exercises that contribute to the development of communicative competence in the students who master Academic English in the framework of distance learning.

The examples are listed below:

- Personal vocabulary to tackle the underdeveloped vocabulary and expand students active and passive thesaurus;

- Permanent learning and repetition of clichés and expressions of Academic English in a given technical field;

- Necessity and importance of participation in online projects, groups, student and youth forums and communities. This could eliminate the fear of online communication. Daily chat communication with groupmates and friends will allow students to acquire useful information and feel comfortable at the new sphere of distance education. It is recommended to find virtual communities in thematic forums or groups on social media, participate in interest forums, webinars, master classes, video conferences, etc.;

- It is critical to write 3-4 expressions from various spheres of life with their definitions, invent stories and tell them to classmates online. They, in turn, could write their words and present their stories. After presenting a story, it is to be retold and reviewed to the group mates, trying to select the proper synonymous words and expressions. In this way memory is trained and vocabulary is expanded. This exercise could help to develop meaningfulness, clarity, and expressiveness in speech and will relieve tension and fear when speaking in public;

- It is necessary to present the listened material orally in order to provide the online thoughts expression, one need to constantly practice, therefore, it is recommended to daily pronounce any text, poem, pieces of literary works, business letters, pages of a contract or even a piece technical instruction for a household appliance, etc. The objective is not to learn the text, but reproduce it from memory, using synonyms.

\section{Estimation results of using methodology}

Testing the effectiveness of the methodology was based on testing students before (March 2020) and after (January 2021) the implementation of this methodology. The testing was based on a questionnaire survey of students. The questionnaire contained the following claims that the students needed to select:

1. I am fluent in rhetorical techniques in the current situation of distance learning.

2. I do not have linguistic difficulties in perceiving the material; I am able to paraphrase the source material thanks to the formed communicative competence.

3. I have a well-formed communicative base, a large vocabulary, a stock of linguistic forms, phrases, allowing me to quickly adapt to the existing learning conditions.

4. I am aware of the rhetorical culture of the student and teacher when working on online platforms. 
5. I think that the instructor is a worthy interlocutor, and I try to communicate on an equal footing in the Internet space.

6. I understand the importance of speech etiquette in communicating with lecturers and classmates.

7. I possess communication skills; I am not afraid of public speaking at online seminars and discussions.

8. I am pleased with the instructor's activities, their communication skills and personal qualities demonstrated in communicating with students in the distance learning environment.

9. I am in the constant search for acquiring knowledge, ready to self-develop and improve, despite learning online.

10. There is an ethical component in my rhetorical culture.

11. I am familiar with the concepts of the "addressee" and "interpretive direction" in the student's speech.

12. I have mastered the skill of public speech when learning online.

13. When teaching online, the instructor puts pressure on the student, insults and shows rudeness and sarcasm in case a student's answer is incorrect.

The respondents were supposed to rate the degree of satisfaction with their communicative competence and image in the distance learning environment. The scale of answers was unified, each statementimplied five different answers. Each option valued from -2 to +2 . The answer options were evaluated as follows:

-2 points - very small extent;

-1 point- small extent;

+1 point - greater extent;

+2 points - very large extent;

0 points - more or less.

The test results are shown below.

At the first stage (in March 2020), 181 students were interviewed. Of these, 33 students scored from 16 to 24 points, 40 students scored from 8 to 15 points, 108 students scored from 0 to 8 points.

At the second stage (in January 2021), after the introduction of the methodology of information and communication technologies developed by the authors, 181 students were also interviewed. Of these, 136 students scored from 16 to 24 points, 30 students scored from 8 to 15 points, 15 students scored from 0 to 8 points.

Thus, the conducted sociological survey showed the high efficiency of the proposed methodology. 


\section{Discussion}

Students who scored from 16 to 24 points had an excellent opportunity to receive and transform communication skills or even master new knowledge when learning online. Distance learning was easily accepted and became the major assistant along with the traditional education system, which could not perform its functions in the conditions of the Covid-19 pandemic. This student group easily adapted to the circumstances, which led to a serious change in the field of education.

Such students receive satisfaction from online learning, they know how to study and acquire education at their own pace, according to theirindividualschedule. They have the ability to concentrate on the most important things, avoiding unnecessary information. The personal traits result in getting maximum satisfaction from distance learning.

Group of students who scored from 8 to 15 points showed fear and anxiety, which arose every time they had to start delivering an online public speech. This indicated insufficient components of communicative, rhetorical and speech culture, as well as not enough attention to the aspects that constitute the phenomenon of the student's communicative image in online learning environment. This group requires understanding of the need tofurther self-develop and self-improve, reflecting on the ways to cope with temporary setbacks and eliminate shortcomings in educational activities of distance learning.

The personal qualities of the students scoring from 0 to 8 points, their communication skills and abilities, to a large extent, limited the range of their actions to a number of simple tasks through studying a textbook. Their problem was defined as inability to interpret the material online so that it is clear to the addressee. This respondents group are aware of certain aspects of online communication, but they did not create the communicative image, possessing insufficient understanding of their professionally oriented ability to use the information as a source of knowledge that would contribute to their further advancement and growth in learning. For this group is necessary self-improvement and painstaking work on their communicative competence and speech culture are necessary, as well as the permanent development of communication skills and abilities in distance learning. All these aspects could help the students understand their function in the framework of obtaining knowledge online by receiving and using the knowledge that they will need in their future professional activity, in achieving educational goals.

\section{Conclusion}

Thus, the study features the practical foundations of the application of information and communication technologies in the implementation of distance education at technical faculties in teaching Academic Englishon the basis of experimental training in the Covid19 pandemic. The survey analyzes the experience of implementing information and communication technologies in teaching Academic English at Ogarev Mordovia State University; it shows the practice of communicative technologies management within the framework of academic communication on the basis of innovative principles for the 
development of language competence. The conducted survey-questionnaire among students was carried out in order to clarify the importance, need and promising possibilities of distance learning, which allowed to determine the methodological possibilities of distance education in teaching English in order to predict the organizational structure of modern communication technologies and created the basis for the development of theoretically justified methodological principles in the organization of distance education in Academic English. The research findings assisted the researchers of Ogarev Mordovia State University in developing the modern information and communication tools, including educational and methodological video and distance complexes.

\section{References}

Foung, D., \& Chen, J. (2019). A Learning Analytics Approach to the Evaluation of an Online Learning Package in a Hong Kong University. Electronic Journal of e-Learning, 17, $11-24$.

Gao, L.X., \& Zhang L.J. (2020). Teacher Learning in Difficult Times: Examining Foreign Language Teachers' Cognitions About Online Teaching to Tide Over COVID-19. Frontiers in Psychology, 11, 549653. http://dx.doi.org/10.3389/fpsyg.2020.549653

Gleason, B., \& Manca, S. (2020). Curriculum and instruction: pedagogical approaches to teaching and learning with Twitter in higher education. On the Horizon, 28(1), 1-8. https://doi.org/10.1108/OTH-03-2019-0014

Ho, N.T.T., Sivapalan, S., Pham, H.H., Nguyen, L.T.M., Pham, A.T.V., \& Dinh, H.V. (2020). Students' adoption of e-learning in emergency situation: the case of a Vietnamese university during COVID-19. Interactive Technology and Smart Education. https://doi.org/10.1108/ITSE-08-2020-0164

Lebedev, A.V., Bobrova, N.E., \& Pinkovetskaia, I.S. (2020). Peculiarities of the English Legal Text Discourse: The Issues of Interpretation and Translatability. Journal of History Culture and Art Research, 9(2), 318-328. http://dx.doi.org/10.7596/taksad.v9i2.2689

Marcum, J., \& Kim, Y. (2020). Oral Language Proficiency in Distance English-Language Learning. CALICO Journal, 37, 148-168.

Martin, I.A. (2020). Pronunciation development and instruction in distance language learning. Language Learning \& Technology, 24(1), 86-106. https://doi.org/10125/44711

Murneva, M.I., Shestakova, N.A., \& Samoilova, E.V. (2018). The modern technology of teaching English at non-linguistic faculties: science or art? Philological Sciences. Problems of theory and practice, 3(81), 415-418.

Vaganova, O., Ilyashenko, L., Smirnova, Z., Bystrova, N., \& Kaznacheeva, S. (2019). Students' creative abilities development in higher educational institution. Amazonia Investiga, 8(22), 701-710. $\quad$ Retrieved from https://amazoniainvestiga.info/index.php/amazonia/article/view/822

Vaks, V.B. (2021). Research of certain aspects of digitalization of the educational process in the university. Scientific-methodical electronic journal "Concept", 1-13. http://ekoncept.ru/2021/211004.htm/ 